\title{
Notes on Variation and Self-incompatibility in Japanese Flowering Cherries
}

\author{
by Kotaro WATANABE* and Katsuyoshi YoshikAwA**
}

Received April 28, 1967

\begin{abstract}
Five species of the Japanese flowering cherries (Prunus jamasakura Sieb., ex Koidz., P. lannesiana Wils. var. speciosa Makino, $P$. sargentii Rehd., P. subhirtella Miq. var. pendula (Maxim.) Y. Tanaka, and P. yedoensis Matsum.) are self-incompatible. Prunus yedoensis has been propagated only by vegetative reproduction, and the incompatibility was seen in intra- as well as inter-individual pollination: the naturally occurring scanty fruiting may be due to cross-pollination with other species. The remarkable variations in Prunus jamasakura are also partly attributable to the self-incompatibility.
\end{abstract}

Prunus jamasakura is known by its remarkable variations in morphological and phenological features ${ }^{1,2)}$. In the previous papers ${ }^{3,4)}$ these variations were described in detail with 16 trees growing in the yard of the Faculty of Agriculture, Kyoto University***. The majority of these variations may be of hereditary nature, for all trees were grown under almost the same circumstance. Correlation between the prevailing air temperature and the number of days from flower-bud appearance to full bloom was highly significant for the yearly fluctuation (average value of measurements in all trees was taken for each year), while it was insignificant for the individual fluctuation (average value of the 11 years' measurements was taken for each tree). This complexity may also be, at least in part, due to the large differences of the trees.

A contrast was noticed in the fruit-setting between Prunus jamasakura and $P$. yedoensis. The former bears many fruits, while the latter sets fruits scantily in spite of its abundant flowers. From the preliminary experiments performed in 1959-1961, it was confirmed that both species were sterile after self-pollination****. In the genus Prunus, self-incompatibility was known in sweet cherries and plums ${ }^{6-8)}$ and so, in the present article, further investigation was undertaken concerning self-incompatibility in the following species of the Japanese flowering cherries. They were Prunus

* Laboratory of Applied Botany, Faculty of Agriculture, Kyoto University, Kyoto, Japan.

** Experimental Forest Station, Faculty of Agriculture, Kyoto University, Kyoto, Japan.

*** Characters examined were as follows: Dates of leaf sprouting, flower-bud appearance, full bloom, and flower fall; intervals between these characters; size and form of petals (flowers); number of stamens; length of pedicels; colour of buds and flowers; degree of flower opening at the time of full bloom; epinastic outward bending of sepals; development and colour change (brown to green) of leaves after sprouting; size and form of leaf blades; length of petioles; number of leaf veins; position of extra-floral nectaries; mode of hair development on leaf blades; time of leaf fall, etc.

**** As to $P$. yedoensis imperfect self-sterility was suggested by Iwasa and Itami5) in 1961. 
Table 1. Pollinations of Japanese flowering cherries.

\begin{tabular}{|c|c|c|c|c|c|c|c|}
\hline \multicolumn{4}{|c|}{ Combination } & $\begin{array}{l}\text { No. of } \\
\text { flowers }\end{array}$ & $\begin{array}{c}\text { After 2-3 } \\
\text { weeks } \\
\text { Fruit-set. } \\
\%\end{array}$ & $\begin{array}{l}\text { After } 5-6 \\
\text { Fruit-set. } \\
\%\end{array}$ & $\begin{array}{l}\text { weeks } \\
\text { Seed-set. } \\
\%\end{array}$ \\
\hline \multicolumn{8}{|c|}{ Prunus jamasakura } \\
\hline \multirow{12}{*}{ Tree } & III & & Self & 151 & 0 & - & - \\
\hline & $\mathrm{V}$ & & ” & 53 & 0 & - & - \\
\hline & VIII & & $"$ & 23 & 4.3 & - & - \\
\hline & IX & & $"$ & 24 & 0 & - & - \\
\hline & XI & & $"$ & 57 & 0 & - & - \\
\hline & III & $x$ & $\mathrm{~V}$ & 59 & 67.8 & - & - \\
\hline & ” & $x$ & IX & 31 & 51.6 & - & - \\
\hline & $\mathrm{V}$ & $x$ & III & 47 & 53.2 & - & - \\
\hline & $"$ & $x$ & VIII & 57 & 66.7 & - & - \\
\hline & $"$ & $\times$ & IX & 22 & 45.5 & - & - \\
\hline & $"$ & $x$ & $\mathrm{XI}$ & 58 & 1.7 & - & - \\
\hline & $\mathrm{XI}$ & $\times$ & $\mathrm{V}$ & 58 & 1.7 & - & - \\
\hline & VI & $x$ & $P$. yedoensis & 80 & 38.8 & 33.8 & 33.8 \\
\hline & XIV & $\times$ & $"$ & 83 & 69.9 & 65.1 & 63.9 \\
\hline & VII & $\times$ & P. sargentii & 59 & 32.2 & 11.9 & - \\
\hline & $\mathrm{XI}$ & $\times$ & $”$ & 60 & 43.3 & 25.0 & - \\
\hline \multicolumn{8}{|c|}{$P$. yedoensis } \\
\hline \multirow{2}{*}{\multicolumn{4}{|c|}{$\begin{array}{l}\text { Intra-individual ( } 8 \text { trees) } \\
\text { Inter-individual } \\
\text { (between } 5 \text { trees) }\end{array}$}} & 621 & 0 & - & - \\
\hline & & & & 506 & 0.2 & 0 & 0 \\
\hline \multicolumn{4}{|c|}{$\times P$. jamasakura (Tree VI) } & 158 & 7.0 & 7.0 & 7.0 \\
\hline \multirow{2}{*}{\multicolumn{4}{|c|}{ 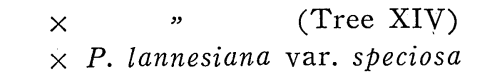 }} & 191 & 12.0 & 1.1 .0 & 11.0 \\
\hline & & & & 69 & 34.8 & 17.4 & 8.7 \\
\hline \multicolumn{4}{|c|}{$\times P$. subhirtella var. pendula } & 87 & 14.9 & 12.6 & 6.9 \\
\hline \multicolumn{4}{|c|}{$\begin{array}{l}\times P . \text { subhirtella var. pendula } \\
\text { f. ascendens }\end{array}$} & 115 & 16.5 & 15.7 & 15.7 \\
\hline \multicolumn{4}{|c|}{$\begin{array}{l}\times \text { A seedling from } \\
P . \text { subhirtella var. pendula } \\
\quad \text { (ascendant) }\end{array}$} & 81 & 24.7 & 23.5 & 21.0 \\
\hline \multicolumn{8}{|c|}{ P. lannesiana var. speciosa } \\
\hline \multirow[t]{5}{*}{ Tree } & $\mathrm{A}$ & & Self & 103 & 0 & - & - \\
\hline & $\mathrm{B}$ & & $"$ & 102 & 0.98 & 0.98 & 0 \\
\hline & $\mathrm{C}$ & & $"$ & 108 & 0.9 & 0 & 0 \\
\hline & $\mathrm{D}$ & & $”$ & 83 & 0 & - & - \\
\hline & $\mathrm{E}$ & & $”$ & 134 & 2.2 & 2.2 & 0.7 \\
\hline & A & $x$ & $\mathrm{~B}$ & 125 & 80.0 & 62.4 & 47.2 \\
\hline & $"$ & $x$ & $\mathrm{C}$ & 83 & 55.4 & 48.2 & 37.3 \\
\hline & $"$ & $x$ & $\mathrm{D}$ & 75 & 44.0 & 25.3 & 12.0 \\
\hline & $"$ & $x$ & $\mathrm{E}$ & 66 & 75.8 & 47.0 & 10.6 \\
\hline & $\mathrm{B}$ & $x$ & A & 101 & 60.4 & 43.6 & 39.6 \\
\hline & $\mathrm{C}$ & $\times$ & A & 83 & 62.7 & 48.2 & 31.3 \\
\hline & $\mathrm{D}$ & $\times$ & A & 46 & 65.2 & 56.5 & 54.3 \\
\hline & $\mathrm{E}$ & $\times$ & $\mathrm{A}$ & 86 & 82.5 & 75.6 & 64.0 \\
\hline \multirow[t]{2}{*}{ Tree } & $\mathrm{A}$ & $\times \quad F$ & P. yedoensis & 54 & 53.7 & 20.4 & 13.0 \\
\hline & $\mathrm{B}$ & $x$ & $”$ & 17 & 70.6 & 47.1 & 41.2 \\
\hline
\end{tabular}




\begin{tabular}{|c|c|c|c|c|}
\hline \multicolumn{5}{|l|}{ P. sargentii } \\
\hline Tree $\mathrm{M}^{*}$ & 82 & 0 & -- & - \\
\hline$M^{*}$ & 44 & 27.3 & - & - \\
\hline \multicolumn{5}{|l|}{ P. subhirtella } \\
\hline Self & 40 & 0 & - & - \\
\hline$\times P$. subhirtella var. pendula & 60 & 3.3 & 1.7 & 1.7 \\
\hline$\times P$. yedoensis & 96 & 11.5 & 4.2 & 1.0 \\
\hline \multicolumn{5}{|l|}{ P. subhirtella var. pendula } \\
\hline Self & 74 & 0 & - & -- \\
\hline $\begin{array}{l}\times P . \text { subhirtella } \\
\quad \text { var. pendula f. rosa }\end{array}$ & 55 & 65.5 & 61.8 & 61.8 \\
\hline \multicolumn{5}{|l|}{ P. subhirtella var. pendula f. rosa } \\
\hline Self & 31 & 0 & - & - \\
\hline$\times P$. subhirtella var. pendula & 17 & 11.8 & 5.9 & 0 \\
\hline
\end{tabular}

* Water culture; Twigs were reared with $1.5 \%$ sucrose solution.

jamasakura, $P$. yedoensis, $P$. lannesiana var. speciosa, $P$. sargentii, $P$. subhirtella, $P$. subhirtella var. pendula, and $P$. subhirtella var. pendula f. rosa. These were selected from the trees in the yard of the Faculty of Agriculture and in the Forest Station of the University, Kamigamo, Kyoto. Twigs with flower-buds were isolated with paper bags. When the flowering time between partners was different, the pollen grains of the earlier-bloomed one were preserved in a desiccator for 1 to 5 days. These pollen grains germinated well and developed pollen tubes on agar media containing $7 \%$ sucrose and $0.01 \%$ boric acid. All the 3 trees of Prunus sargentii were so tall that the twigs with flower-buds, about $50 \mathrm{~cm}$ in length, were cut off and reared with $1.5 \%$ sucrose solution.

Usually the calyx-tubes dropped off about a week after pollination exposing the developing ovaries. In cases of illegitimate pollination the tubes remained on the receptacles for a while, even when the absciss-layer was made. The ovaries of the self-pollinated flowers of Prunus lannesiana var. speciosa and $P$. sargentii, however, showed a slight growth until the calyx-tubes were shed off. Therefore, it was necessary about 2 to 3 weeks after pollination to estimate the compatibility. In the experiments performed in 1963 and 1966 the observations were repeated 5 to 6 weeks after pollination to get final percentage of the obtainable fruits and seeds.

The results summarized in Table 1 indicate that in the self-pollination of these species, no or only a few fruits were produced, though in Prunus subhirtella and $P$. subhirtella var. pendula f. rosa repetition of experiment may be necessary. In $P$. yedoensis no fruits were obtained, even in inter-individual pollination. Also in this species the ovaries sometimes developed to some extent in illegal pollination, but soon they ceased their growth and fell off with the pedicels. On the other hand, some ripe fruits (about $10-20 \%$ of pollinated flowers) were gained in pollination by $P$. jamasakura, P. lannesiana var. speciosa, $P$. subhirtella var. pendula, and so forth. In $P$. lannesiana var. speciosa only one ripe seed was obtained from 530 self-pollinated flowers on 5 trees. Tree $\mathrm{E}$ yielded many ripe seeds when pollinated by tree A, while from the reciprocal pollination much less seeds were produced in spite of rather good initial fruit-setting. In $P$. jamasakura both the combinations of tree $\mathrm{V} \times$ tree $\mathrm{XI}$ and its reciprocal produced only one fruit, suggesting that they belonged to the same cross-incompatible group. In other intra-specific crosses about $50-70 \%$ of pollinated 
flowers showed initial fruit-set.

Among the Japanese flowering cherries, the following species can be enumerated as self-incompatible: Prunus jamasakura, P. lannesiana var. speciosa, P. sargentii, $P$. subhirtella var. pendula, and P. yedoensis. Prunus lannesiana var. lannesiana, which comprises various double-flowered cultivars, may also be self-incompatible, for the flowering cherries belonging to this variety have been derived, mainly, from $P$. lannesiana var. speciosa, $a^{9,10}$.

Prunus yedoensis, which is believed to be a hybrid between P. subhirtella var. pendula f. ascendens and $P$. lannesiana var. speciosa ${ }^{11,12}$, is propagated by means of grafting onto Prunus lannesiana var. lannesiana f. multiplex or P. lannesiana var. speciosa, and produces few fruits under natural conditions. The self-incompatibility of this species is not only of intra- but also inter-individual nature. Inter-specific pollinations are possible to form fruits. Therefore, the fruits set on these trees are to be regarded as hybrids with some other species growing in their vicinity. In P.jamasakura, on the other hand, many fruits are usually produced by intra-specific pollination, so that it multiplies itself with seedlings as in cases of $P$. sargentii, $P$. lannesiana var. speciosa, etc., and, as mentioned above, remarkable variations in morphological and phenological features have been observed in this species.

Grateful acknowledgement is due to Prof. S. Imamura and Assoc. Prof. M. Hamada for their advice and criticism throughout this study. Thanks are also due to Dr. Y. Kitani and Dr. S. Nakamura of our Faculty for their kind advice and assistance in the course of this work.

\section{References}

1) Miyoshi, M., J. Sci. Coll. Imp. Univ. Tok yo $34: 1$ (1916).

2) - "Sakura". Fuzanbō, Tokyo (1938) (Japanese). 3) Watanabe, K., Imamura, S., and Yoshikawa, K., Bull. Kyoto Univ. For. no. 35 : 39 (1964) (Jap. with Eng. summary). 4) Watanabe, K., Yoshikawa, K., and Imamura, S., ibid. no. 38 : 76 (1966) (Jap. with Eng. summary). 5) Iwasa, R., and Itami, K., Jap. J. Breed. 11:236 (1961) (Jap., summary of lecture). 6) Sutton, I., J. Genetics 7:281 (1918). 7) Crane, M. B., J. Genetics $15: 301$ (1925). 8) Hrubý, K., Biol. Plant. $4: 54$ (1962). 9) Ohwi, J., Flora of Japan. Revised ed. Shibundō, Tokyo (1965) (Japanese). 10) Makino, T., "Shokubutsu-ki" (Descriptions on plants). 2nd ed. Sakurai-Shoten, Tokyo (1946) (Japanese). 11) Takenaka, Y., Bot. Mag. Tokyo $75: 278$ (1962) (Jap. with Eng. summary). ibid. 78 : 319 (1965) (Jap. with Eng. summary).

\section{摘 要}

\section{渡辺光太郎* ·吉川勝好**：サクラの変異と自家不和合性}

ヤマザクラ Prunus jamasakura・エゾヤマザクラ P. sargentii・オオシマザクラ P. lannesiana var. speciosa・イトザクラ P. subhirtella var. pendula およびソメイヨシノP. yedoensis には, いずれも自 家不和合の性質があることがわかった。ソメイヨシノは自家・他家受粉とも種実を形成しない. この植物の 結実は他種のサクラとの交雑の結果と見てまずあやまりがない.

われわれは多年同一地域の, ほら゙同じ環境下にある 16 本のヤマザクラについて調査し，開花状態や花・ 葉などの諸形質に顕著な個体差のあることを認めた・自家不和合性は，このような著しい変異を生ぜしめた 一因であると考えてよかろう。(*京都大学農学部応用植物学研究室・**京都大学農学部附属演習林) 